\title{
The Right of Immigrants to Vote in Local Elections in Greece
}

\author{
Darjel Sina, PhD \\ Lecturer at the European University of Tirana \\ Cel: +355694464748/darielsina2002@yahoo.com \\ Arjan Vasjari, PhD \\ Lecturer at the European University of Tirana \\ Cel: + 355686031506/vasjaria_al@yahoo.it
}

Doi:10.5901/ajis.2013.v2n2p19

\begin{abstract}
Legal regime of foreigners in Europe has gained in recent years after a change of populations of particular importance that grow over the years (Vlahos G., Legality of persons and individuals, Volume of the Greek Supreme Court II, 1982, pg. 25, Venizelos E., European Citizenship and the Greek Constitution,Greek Legal Rewiev EEEyrD, 1993, pg. 271). This paper will look as a host country of emigrants. The large number of immigrants was certainly due to her disorder in the Greek population. The biggest challenge of the present and future is the integration of foreigners into the Greek society, which relates to integration of a number of legal issues related to the principle of equilibrium (by country of origin) and the principle of proportion (Dimitropoulos G. A., The Constitutional Rights of the foreigners in Greece, 2004, pg. 10). Sanctions and protection of any kind of a right of immigrants is a condition self-understanding, which should always be taken into account in Greece and not only there, but in any state that is founded on the principles and values of modern democracy. Given this principle, Greece in its recent law that was passed by the Greek Parliament approved by a majority of voting rights of immigrants resident in Greece and the right to be elected as members of the municipal councils or municipal councils if they possessed residence permit required by this law (Pasok party voted in favor and two far-left party SIRIZA, and the right against two parties, Laos and Nea Dimikratia, while the Communist Party voted abstention). The truth is that this law constitutes a legal innovation for Greece, a country that suffers from a lack of modern legislation on the legal treatment of foreign nationals who were permanent resident in Greece (Kakalis P., Greek legislation, the right of foreigners, 2005, pg. 45). On the following pages will analyze the background of the establishment of the Greek legislation on foreigners, the rights accorded to them by the law of 2010 (3838/2010), which will essentially be viewed in sections 14-21, stipulating the franchise of foreign immigrants in Greece, their right to be elected in local elections and the decision of the Greek court which seeks cancellation of articles based on the principle of popular sovereignty and several other articles of the Constitution Greek ( Papasiopi,Pasia. Z, The new Law 3386/2005 for foreigners, Thoughts and problematics, 2006, pg. 43.).
\end{abstract}

Keywords: Foreigners, immigrants, integration, rights, principle

\section{The case of Greece}

The immigration policy means all institutional arrangements and informal practices aimed at tackling the issues that arise and needs arising from the phenomenon of migration, both at reception and in immigrant integration and social security level to ensure cohesion (Venieris $S$ pg. 15.). Immigration is a complex reality, which affects all parameters that make up a modern welcoming to immigrants. For this reason, immigration policy includes all political interference asking for the necessary institutional framework for effective implementation (Papagianni G., pg. 39.). Therefore, immigration policy is part of the overall policy for the society, economy and social cohesion. In this sense, immigration is seen as a critical area of development policy and practice in relation to public safety and economic development requiring a planning and effective implementation of immigration policies (Varouksi Ch., Saris N, Frankiskou A., pg. 33). Given that in two decades Greece has experienced a wave of high emigration (mostly illegal immigrants), this phenomenon became an important 
area of policy exercise, as it constitutes a factor in creating the conditions for economic development, demographic, legal and social (Varouksi Ch., Saris N, Frankiskou A pg. 36). An important question to put to exercise effective immigration policy is the ability of public administration in Greece to design and effectively implement policies that ensure the integration of immigrants in the general framework set out economic restructuring, the social and institutional provisions of the regulations at national and European level given its negative elements that are (Sitaropoulos N., pg. 120):

1. The geography of Greece, the land and sea borders which are difficult to control and allowing easier access to people from neighboring countries (The greek society for the international private law, The Greek regime of the foreigners, 1995, pg. 89).

2. Stability and prospects of the Greek economy within the European Monetary Union assessed (not already) to create a good condition and secured to form economic policy and social conditions and employment of immigrants residing in the country (Papagianni G., pg. 60).

3. The large number of small businesses, large rural and agricultural sector, tourism, informal economy (Amicis G \& Lazaridhis G., 2001 , «Adjustments immigration policy in Greece », 2001, pg .27. It is estimated that the informal economy is around 30\% of GDP in Greece) that characterize the Greek economy (Kamberis N, «The foreigners worker in Greece on the agriculture sector» , 2006, pg. 417).

\subsection{Separation and terminology of the term "Foreign"}

The definition of foreigner: Foreign natural persons are those who do not have citizenship of the country where they live and are holders of a citizenship of another country or do not have any citizenship (The right of foreigners apply to foreigners).

Homogeneous and Allogien: Foreigners with their distinct nationality criterion in homogeneous and allogien (Homogeneous as coming from the Greek word which means-born citizens who come from the same nation, while allogjen means descent citizens coming from different nations). Homogeneous is a person who does not possess the nationality of the country, but the nation of his (the Albanian Kosovars case). Allogien is a person who belongs to another nation(Dagtoglou P., Constitutional Right, Human Rights, 2005, pg. 432)

Extracommunitare: nationals of a third country which does not have a European citizenship under Article 17, first paragraph of the EU Convention (Lillich R., International rights problems of law, policy and practice, New York, 2006, fq. 260, Bogusz B./Cholewinski R., pg.210, Bauboeck R. pg. 140).

\subsubsection{The foreign community:}

Foreign nationals community are EU members. 17 Pursuant to the provisions of the Convention stated that the EU "citizenship to approve a European Union citizen who is a natural person who possesses the nationality of a Member State". Citizenship of the Union complements and does not replace national citizenship (Bauboeck R., pg. 100).

\subsubsection{Natural person without citizenship:}

Such a person is a person who does not possess any citizenship of a country that meets the requirements of the New York Convention of 1954 that regime dedicated individuals without citizenship (Vrellis S., pg. 189).

\subsubsection{Refugees:}

Refugees are foreigners who fulfill the requirements of the Geneva Convention of 1951 and Protocol of 1967 to the legal regime of natural persons, who for reasons to justify fear, persecution for reasons of race, religion, nationality, or political beliefs are abroad (Voulgaris CH.,, pg. 56, Forsythe D., pg. 128).

\subsection{The rights of foreigners in national and universal human}

The right of foreigners held in three levels: Constitutional, Legislative and International (Article Neni 28 of the Greek Constitution cited that"International Agreements has a superiority against the national legislation"). The rights of foreigners differ classical division of rights in the public-private-constitutional and civil. Basic provisions which constitute a 
legal regime of aliens in these established constitutional and legal spectrum of facing legal aliens and partly in private-civil rights. In Greek Constitution the rights of foreigners (like Greek nationals) found in the chapter on fundamental rights (Articles 4-25). Greek legislator has tried often to face the problem of immigration which is trying to cope with laws and presidential decrees (Varouksi Ch.,./\&Saris N, Frankiskou A., pg. 40). The first law was a result of the high rate of illegal immigrants entering Greece from its border every gate and was Law no. 1975/1991 (Amicis G \& Lazaridhis G., pg. 27), which was followed by presidential decrees of 1997 (358 \& 359/1997 Dagtoglou P., pg. 500.), which was followed by Law no. 2910/2001, which replaced Law no. 1975/1991. At 2005 law no. 3304/2005 which replaced Law no. 2910/2001, which was followed by Law no. 3731/2008 and later in 2010 the last law no. 3838/2010. By law no. 3838/2010 with "modern provisions for Greek citizenship and political participation homogenous and legal immigrants and other adjustments (Official Journal 49/24.3.2010) provide the possibility of obtaining Greek citizenship from the children of immigrants, amend the terms and procedures for citizenship through the naturalization of foreigners, and is known for eligible Residents of voting rights and the right to be elected in the first elections of local government that took place in November 2010 (Sitaropoulos N.,pg. 36, The Greek society for the international private law, Legal regime of the foreigners in Greece, 1995, pg. 230, Kakalis P., pg. 90, Papasiopi Pasia Z pg. 150).

\section{Universal human rights}

Some Constitutional rights sanctioned by the Constitutions for all individuals, regardless of nationality, age or any other characteristic (So with the exception of the right to vote and determine the collection of taxes as American Revolution (1776), as the French (1789) sanctioned individual rights for all people and not only for U.S. citizens or French.). In this sense the carrier and the subject of those rights is the man (Under Article 126 of the Civil Law 2783/1941 "Foreigners entering the jurisdiction of local courts and have the right to sue as under the provisions locals. According to Article 5 of the CC Greek "criminal laws apply to all acts committed in the territory of the state and the perpetrators were strangers".). In this category we are dealing with human rights which are enshrined not only to Greek citizens, but also foreigners or stateless persons. It's irrelevant if we are dealing with immigrants legal or illegal, inside or outside the EU. These rights have a universal character which is recognized by sanctioning their right to all citizens without exception (Dimitropoulos G. A., pg.14.).

\subsection{National rights}

Besides the universal rights have constitutional rights which sanctioned only for citizens of the country concerned (Dagtoglou P., pg. 450, Dimitropoulos G A., pg. 11). The same contrast level and not just the Greek Constitution. The question which arises is sanctioned and recognized rights to foreigners (Constitutions in the world have a classification of rights where the majority of their political rights enshrined in the relevant country nationals). For this reason it is important division of constitutional rights to equal political, economic and social. Economic and social rights normally given to local citizens but also foreigners, and political rights recognized as a rule only for local citizens (Dimitropoulos G. A., pg. 874.). Also securing rights, ie rights that include the recovery of a claim or provide a service or its provision by the state towards its citizens, primarily known only to local citizens (As might be right to education. In Greek Constitution stipulates this right in Article 16 thereof and contains a fair recovery of the citizen to Greece for a free public education coupled with some other conditions that the Greek government should provide its citizens).

\subsection{Participation in political and constitutional sanction}

Article 5, paragraph 1 of the Greek Constitution guarantees the right of "everyone" to take part in the political life of the country. According to this article the Greek Constitution and the principle of participation in the political life of the country that ratifies this section, the aliens may have political views and their ideology that can be expressed freely, but foreigners can not participate in the formation of the will through political or parliamentary elections in the exercise of state power. This limitation is the result of the clear provisions of the Greek Constitution under which foreigners have no right to vote and be voted (in the spirit of parliamentary elections this article is already considering the purpose of the new Greek immigrants to vote in local elections). These restrictions are binding for the Greek legislator and can not lift or set exceptions. 


\subsection{The creation of a political party:}

Article 29, paragraph 1 of the Greek Constitution provides the right of establishment and participation in political parties only Greek citizens who are eligible to vote. Thus it is clear that "it is not inconceivable and considered in accordance with the principle of popular sovereignty of foreign participation in the exercise of state power. So political activity and the possibility of establishing or operating in Greece of foreign political parties is not guaranteed in Constitution (Article 29, paragraph 1 states that only "Greeks" who are entitled to vote may freely establish and join political parties. Political activity is exercised or within political parties or other outside party framework, Article 16 of the European Convention on Human Rights permits the imposition of restrictions on political activity of aliens). The purpose of political parties is receiving power (Kakalis P., pg. 88), so foreigners can not have such an opportunity which is against the concepts of sovereignty and independence, which are the foundation of the Greek state (of any rule of law). For Hence the creation of political parties and their functioning by foreigners in the Greek territory constitutes an unconstitutional legal action (Vrellis S., pg. 50, Dagtoglou P., Constitutional right, Human Rights, 2005, pg. 320, Sitaropoulos N., pg. 230).

\subsection{Participation of foreigners in political parties or user quality shock}

Unlike the case of the establishment and functioning of political parties of foreign simple participation of foreigners in the Greek political parties can not lead to the result of taking power by aliens, action which would be in conflict with the sovereignty and independence of the Greek nation state. Of course, such participation should not be a size that can reach to change the character of the political party in a foreign party. So there is a possibility to allow such participation. However foreigners can not in any way take important positions within the party after such a move would bring an exercise of state power by them (Particular case is the participation of foreigners in the quality Pasok party of friends and member).

\section{Constitutional and Political Rights.}

Constitutional political rights that ensure participation in the narrower sense of the term, in the exercise of political power: the right to vote and the right to vote, the right to which the Greek Constitution are known only to the Greeks. In a democratic society, citizens should participate actively in policy. We all feel the need to express their opinions and raise their voice against the gross injustices suffered by state authorities. All Greek citizens who have reached the age of 18 years are entitled to their vote to declare their preference for a political party or a political person. Foreigners were not recognized political rights of its kind in the Greek Constitution. As regards the right to appoint a state post under article 4, paragraph 4 of the Greek Constitution stated that "Only Greek citizens can be admitted to state positions" with some exceptions that refer to European citizens and homogeneous individuals.

\subsection{The right to vote}

The right to vote: The Greek constitutional order, is the direct electorate exercised his power through the right to vote. Also electorate exercises its discretion when invoking a referendum to decide on an issue of national importance or voted for the draft law (laws) that govern unless serious social issue bills with economic and budgetary restraint. The Constitution in Article 51, third paragraph establishes the conditions for determining the individuals who make up the electorate. These under Section 4 of Presidential Decree are: "1. The right to vote have Greek citizens who have reached the age of 18 ', 2. Possess legal capacity and 3. The right to vote is not removed with a final decision by a conviction for a criminal offense.

\subsection{The right to choose}

The right to choose: The right provided for in Article 55 of the Greek Constitution and the rights that a Greek citizen to establish his candidacy to be elected representatives of the people in the Greek parliament. Under Article 55 first paragraph are three elements which must meet a candidate: 1. Possession of Greek citizenship. 2. Legal capacity and the right to vote and 3 . Age 25 years that the candidate should be filled until the day of the election. 


\subsection{Article 14 of Law 3838/2010}

\subsubsection{The right to vote}

19. Extracommunitare homogeneous and foreigners can take part in local elections with voting rights if:

1. They have reached the eighteenth year of their age.

2. There have been sentenced by final judgment for a crime of which were removed according to which political rights as do the Greek citizens in accordance with Articles 59 and 60 of the Criminal Code.

\subsubsection{Enter one of the following categories of foreigners living legally resident:}

a. Are holders of a special identity card which was given homogeneous citizens.

b. Are holders of a permanent residence permit or ten-year period, in accordance with the provisions of Law 2910/2001 (Official Gazette 91 A) and paragraph 2 of Article 91 of Law 3386/2005, as amended;

c. Are located in the status of immigrants with long-term residence in accordance with the provisions of Presidential Decree 150/2006 (Official Gazette A 160).

d. Are holders of a "permanent resident card", as family members of a Greek citizen or a citizen of a country's citizen of the European Union in accordance with the provisions of article 63 of Law 3386/2005 and Article 17 of Presidential Decree 106/2007 ( GG 135 A),

e. Parents of minor children are Greek, according to article 49 of Law 3386/2005, as in force, and have reached five years of continuous residence in the country.

f. Are recognized as political refugees or were placed under protection for humanitarian reasons in accordance with the provisions of Presidential Decree 61/1999 (Official Gazette 63 A) and Presidential Decree 90/2008 (Official Gazette 138 A) 96/2008 (GG 152 A), 167/2008 (GG 223 A) and 81/2009 (Official Gazette 99 A), as amended, if they have five years of continuous residence in the country.

g. Holder or travel documents are identity cards are issued by a local authority, under the provisions of the International Convention of New York terms of citizens without citizenship regime, which has been ratified by Greece by law no. 139/1975. These individuals must have completed five years of legal residence in the country of their demand for the release of these documents. Legal residence in Greece confirmed through an official document which is issued by the competent authority.

\subsubsection{Article 15 Application form in specific catalogs election}

a. Persons belonging to one of the categories listed in the previous article and wish to exercise their right to vote must submit an application for inclusion in a special catalog of municipal election in which municipalities submitted a request to issue a residence permit which are in the possession and continue to reside in the same municipality.

b. Beneficiary who is entitled to be registered in the catalogs mentioned if the address has changed is applying to join the new catalogs in the municipality where he resides.

c. Application specific catalogs recorder must be accompanied by:

d. A copy signed by the issuing authority of the residence permit. For registration in this catalog does not replace the copy of the delivery confirmation of documents for obtaining a residence permit.

e. A signed copy of the passport issuing authority. Excluded those individuals who, for objective reasons can not submit this document.

f. Documents required for proof of completion of 10 years of legal residence in the municipality, in particular catalogs which will be completed registration, if required by the provisions of the current law. For 10-year certificate of residence required a certificate from the municipal authority.

g. Criminal record.

\subsubsection{Article 16 The right to vote}

1. The right to vote is exercised exclusively by the registered voters in special catalogs that are created on the 
basis of the previous article.

2. Those individuals are listed in a separate catalog vote along with other voters at polling stations established in accordance with requirements.

3. Identification of voters head showing a residence permit and a valid passport when it is needed.

\subsubsection{Article 17 The right to be elected}

1. Registered voters in special catalogs under Article 15, who on Election Day, birthday reached twenty-one years may be elected members of the City Council or Municipal provided that they possess the Greek language for the exercise of their duties.

2. The first paragraph elects candidates declared by a competent court if owning a legal residence permit and possess a valid passport

3. By submitting a declaration of candidacy any candidate single Custodian is required to submit the following documents:

a. Statement of responsibility with which his citizenship states and the address where he lives in Greece, which owns Greek sufficient for the exercise of duties if he is elected and that he is not a candidate for the local elections in Greece in a municipality or another municipality.

b. Proof of enrollment in a special catalog of the municipality where the candidate appears.

c. Copy of residence permit signed by the competent authority. To exercise the right to elect enough and copy of proof that the alien has submitted his documents for the renewal of the residence permit which has expired.

d. Signed copy of the passport.

\subsubsection{Article 18 Develop specific catalogs}

1. For voters of Article 14 of this Law drafted electoral lists in each municipality and the municipality containing the following elements:, sex, surname, name, father's name, mother's name, name of husband / wife, the exact date and place of birth (day, month, year), address of residence in Greece municipality or municipal (or local community or, District street and number). If there is no exact date of birth of the voter shall be deemed to be born on January 1 each year.

2. Prior registration in special catalogs election municipalities find the information disclosed to those existing in the electronic archives of the Ministry of Interior. This finding is performed either by sending data that was stated in the relevant branches of the Ministry or by holding any municipal archives on this issue.

\subsubsection{Article 19 Keeping catalogs and specific information. Special Occasions exclusion.}

1. To enroll in special catalogs candidates for deletion, or opposition to any change and evolve through the provisions of Articles 7 to 20 of the presidential decree 96/2007 (Official Gazette A 116).

2. Voters in Article 14 paragraph 1 are excluded from the special catalogs:

a. perform a request.

b. If you eliminate the conditions for exercising the right to vote.

c. If you receive Greek citizenship.

3. Interior Ministry cares for deletion from catalogs, particularly those individuals who were denied the right to vote. For purposes of this paragraph evidence of penalties offices and courts of first instance send the first ten days every two months at the Ministry of Interior catalogs to all data for the recognition of these voters in a special election catalogs.

\subsubsection{Article 20}

For age limit, deprivation of the right to vote, obstacles, inconsistencies and other restrictions of voting rights and any other matters not specifically regulated by the provisions of Articles 14 to Article 19 of this Law shall apply the provisions 
of Presidential Decree 133 / 1997 (official Gazette 121 A), the legislation for the election of deputies and code of the municipalities.

\subsubsection{Article 21}

1. During the first implementation of Articles 14 to Article 20 of this Law, the legal deadline of Article 17 electoral catalogs running for election in November 2010 3.06.2010. By decision of the Ministry of Interior to determine other elements of design catalogs, through communication between public bodies for the implementation of this legislation.

2. In the same decision can be issued a deferment above which extension may not exceed two months.

\subsection{The decision of the Supreme Council of the Greek}

20. According to the decision of the High Council (Greek Supreme Court, which deals with the repeal of laws passed by parliament when these laws conflict with the Constitution) the right to vote in local elections have only Greek citizens, excluding foreigners from the right, contrary to what the law nr.3838/2010 (3.06.2010) for granting citizenship ${ }^{1},{ }^{2}$. The request for withholding of citizenship is accepted by (6) six members and was rejected by a member (1) and the right to vote and the right to choose the foreigners was rejected unanimously by the seven members of the Court. Decision 350/2011 ruled that the law no. 3838/2010 is unconstitutional because it voted against the nine articles of the Greek Constitution $^{3}$ : It violates democratic form of government, enshrined in Article 1, paragraph 2 (popular sovereignty), unrevisable this article, Article 3 (Powers for the People and the Nation). Violates individual rights and social Greek citizens, because it is contrary to Article 4 paragraph 3 of the Greek Constitution (misuse of the elements that must possess a Greek citizen), Article 16, second paragraph 2 (Greek education), Article 21 paragraph 1 (promoting the nation) and Article 25, paragraph 4 (national solidarity). Violates the election of representatives of the Greek people, because it is contrary to Article 51 paragraph 2 (Representation of the Nation) and Article 52 (real-expression of popular sovereignty unforged). Override Local administration because it is contrary to Article 102 paragraph 2 of the Greek Constitution (Election of Local Government Authorities). Finally violates specific provisions of the Constitution, because it is contrary to Article 108 (care for all Hellenism wherever located around the world). Within the nation-state, political constituency compliance with the people is a fundamental principle of democracy (http://news.kathimerini.gr /4dcgi/_w_articles_politics_ 03/02/20110). As a maximalist multiculturalism and so untried giving the right to vote to foreign nationals working in unconstitutional and undemocratic, for this massive release and indigjenizimi aliens undermines the basic principles of democracy and the welfare state, while the notion abrogates defining people as the foundation of political sovereignty. Dimitris Tsatsos (Professour of the Greek Constitutional Right in Greece and Germany and one of the grafting consultant of the Albanian Constitution.) claims so characteristic features unconstitutional granting of voting rights to foreign immigrants. It states that: "On the contrary, we believe that the Constitution and this right is reserved for Greek citizens." Recognition of such rights to foreign nationals require a constitutional amendment. Finally, constitutional changes would be needed to recognize such a right for aliens which did not occur with the 2010 law (Tsatsos D., pg. 164-165). Nation-states created in their participation dimensional, which includes citizens, as well as the

${ }^{1}$ The request for cancellation of the mass citizenship and participation of foreigners in local elections was done in 08/05/2010. Seven judges of the Fourth Division of the Council of State judged unconstitutional law no. 3838/2010, which provides indigenization of foreign nationals living in Greece. For this reason, it sent the case referred to in the panel's final judgment of the supreme court united Repealing. The Court referred specifically to the right to vote and the right to be elected in local government bodies "that right is reserved for Greek citizens and can not be given to those who do not possess this quality, that being Greek. This occurs only with reviewing the relevant provisions of the Constitution. "Consequently, the rules of Articles 14 to 21 of law 3838/2010" are invalid "because contrary to Articles 1, 52 and 102 of the Constitution. Moreover cited by the court that elections for the elected local government are "purely political powers given to these organs, but also because these choices have an impact on political life in general." For Moreover, judges continue, "the exercise of the right to vote in local elections is a mandatory feature for the realization of the principle of popular sovereignty which means the exercise of his constituency and the people as composed only of those individuals who possess the Greek national right to vote

2 Published in the Greek newspaper "TO VIMA" on 01/02/2011.

${ }^{3}$ Meeting of the court was on 114, 18, 21.08.2010 and the decision was published on 1.02.2011. 
possibility of exclusion of some individuals, in case of foreign immigrants, the political community (Joppke Ch., Immigration and the Nation-State, 1999, pg.2). Other studies extend the exclusivity of citizens and social rights. According to data from the Ministry of Interior in special catalogs were compiled for the local elections of 2010 were recorded from 12762 of the total of 190,000 foreign immigrants who meet the criteria for enrollment in these catalogs. Of these, 2,665 are homogeneous and 10097 immigrants of other nationalities. A total of 12762 new voters constitute $0.0035 \%$ of the electorate voting. Since the adoption of Law 3838/2010 to grant citizenship to children of immigrants born in Greece, but also for homogeneous and immigrants who meet the conditions and requirements of the law are made following requirements (Marshall T.H., pg. 72.):

- Because native to Greece or Greek school attendance a 2478 submissions were performed, of which 278 decisions were issued positive.

- For homogenous naturalization applications were submitted 4454 and 1077 were issued positive decisions.

- For the naturalization of immigrants of other nationalities were 2,394 applications submitted that so far there has been no positive decision.

\subsection{The right to vote in European countries}

23. Community voting in local elections and the European Parliament: The European level is worthy to note the decision of the Federal Constitutional Court of Germany in 1994, according to which the right to vote in all levels of decisionmaking is a prerogative of citizens. Similar decisions have been taken in Austria, France and Italy. The right to vote to choose, is an exclusive right of citizens of the EU countries (27 countries), referring analytically: Austria, Bulgaria, France, Germany, Greece, Italy, Cyprus, Latvia, Lithuania, Malta, Hungary, Poland and Romania (Triandafilou A./\& Gropa P., Immigration on the United Europe, 2009, pg. 527.). In other states the right to vote does not apply in an identical manner and inconsistency observed between countries, but no significant differences in the implementation of the law. EU citizens have the right to participate in local elections and European Parliament elections, but not in national elections (This right is in force under the European directive 94/80 EK. Here we examine the provisions relating to the participation of foreign nationals who are not citizens of the European Union).

\subsection{Extracommunitare vote in EU elections}

1. In one (1) state, UK sanctioned the right to vote for foreigners who are not citizens of the EU, but members of the British Commonwealth, with restrictions on the period of legal residence in the territory of the state.

2. In two (2) states, Spain and Portugal, foreigners have the right to vote based on the principle of reciprocity given special historical ties and cultural need to have other countries (ie their citizens) to these two countries (Spain, Portugal In Spain there are reciprocal bilateral agreements in force with Argentina (1988), in Uruguay (1992), Chile (1990), while such agreements are moving forward with Venezulën and Colombia. In Portugal are applicable bilateral agreements with Brazil, Argentina, Venezuela, Uruguay and Chile).

3. In a country (1), Czech Republic foreigners have the right to vote based on the principle of reciprocity between the Czech and the third country has signed an agreement with this (Until now (2013) is not signed such an agreement with a non-member state of the EU).

4. In (8) countries, Belgium, Denmark, Estonia, Netherlands, Slovakia, Sweden, Luxembourg, Finland, the Swiss cantons most foreigners have the right to vote with restrictions regarding the stay.

5. In three (3) countries, Ireland, Luxembourg and Slovenia, foreigners have the right to vote without major restrictions on the period of legal residence in the territory of the state (Newspaper Paron (Greek Review) on 27/2/2011, pg. 33).

6. In Germany, Austria, Italy and France are not allowed foreigners to vote in local elections. France has excluded this possibility by court order in 1992, supporting the idea that local authorities make the most of the second legislative body of France, ie the Senate and consequently the involvement of foreigners in local elections will affect the essence of the principle of sovereignty (Greek Review http://news.kathimerini.gr /4dcgi/_w_articles_politics_3_03/02/2011_431141). 


\section{Conclusions}

By carefully reading this article there is a negative approach of the majority of EU countries to possess the right to vote and the right to choose for foreigners. As stated above such legal action is contrary to the principle of popular sovereignty, a principle recognized by all European constitutions. Giving the right to vote through a law like Greece did think that it is legally wrong. Having regard to the opinion of constitutionalist and popular Greek Dimitris Tsatsos think that the Greek legislator should have amended two constitutional articles 51 and 55 to give foreigners the right to participate and be elected in local elections. Any other action would have legal consequences null because no law is above the Constitution which clearly defines the criteria (which was mentioned) to vote or to be elected. Supremacy of the Constitution is known to the laws in every legal system and constitutional review only those articles can bring legal consequences which sought to bring the 3838 law in 2010.

\section{References}

G \& G Lazaridhis Amicis, "immigration policy adjustments in Greece», 2001.

Bauboeck R., Migration and Citizenship: Legal Status, Rights and Political Participation, 2nd ed., Amsterdam, 2006.

Bogusz B. / Cholewiński R. irregulare migration and human rights: Theoretical, European and International Perspectives, Leiden / Boston, 2004.

Dagtoglou P., Constitutional Right-Human Rights, 2005.

Dimitropoulos G A. Constitutional rights of foreigners in Greece, 2004.

Drosos G,Z. The legal position of the political parties in Greece, 1982.

D. Forsythe, The internationalization of human rights, 1991.

Joppke Ch., Immigration and the Nation-State, 1999.

Kakalis P., Greek legislation. The right of foreigners, 2005.

Kamberis N, "Foreign workers in the agricultural sector in Greece», 2006.

Lillich, R. International rights problems of law, policy and practice, New York, 2006.

Marshall, T. H. Class, Citizenship and Social Development, New York: Anchor Books, 1965.

Papagianni G., Institutional and Policy Dynamics of EU Migration Law, 2006.

Papas A. Position legal aliens under international law, 1972.

Papasiopi, Pasia, Z. The new Law 3386/2005 for foreigners, Thoughts and problematics, 2006.

Greek Society for the private international law, the legal regime of foreigners in Greece, 1995.

Sitaropoulos N., Immigration Law and Management in Greece: Towards an exodus from underdevelopment and a comprehensive immigration policy, 2003.

Triandafilou A. / \& P. Hole, Immigration in the united Europe, 2009.

Varouksi Ch., Saris N, Frankiskou A., (STUDIES - RESEARCH REPORTS NCSR), Images of immigration and immigration policy in Greece today, in 2009.

Vrellis S. The right of foreigners, I, 2003. 